\title{
7 \\ Paul Dibb's Impact on Australian Defence Policy
}

Former Ambassador Kim Beazley

Paul Dibb is indelibly badged in Australian political debate as the creative spirit behind the 1980s Labor Government's defence strategy, which prioritised the defence of Australia. He is guilty as charged. His review of Australian defence capabilities, published in March 1986, and his leadership of the writing team for the 1987 Defence White Paper, The Defence of Australia, are the founding documents. The concept of self-reliance and the geographical priority assigned to Australia's approaches, predated him - these were ideas circulating in the Australian bureaucracy in the 1960s. They emerged as the underpinning of the defence policy of Gough Whitlam's government over 1972-75. Weighed down by the complexities of merging multiple departments into a single Defence Department, and distracted by the tumult around a cataclysmic reforming agenda, Whitlam and his ministers did not, however, have the capacity to put flesh on the bones of the doctrine.

Malcolm Fraser's conservative successor government, in its 1976 White Paper, Australian Defence, encapsulated the thinking in a systematic reading of Australia's changing strategic environment. It produced a paradigm which contemplated 'self-reliance' as a priority, focusing on Australia's approaches geographically. 
Strategic thinking in the previous two decades reflected an approach that was 'outside-in'. Rehearsing the changing strategic environment was almost more important than defining what self-reliance meant. Dibb's approach was 'inside-out', in a sense that was dictated to him by the assumptions given him for his study. The strategic settings were a given and his job was to articulate a capability plan that responded to the exigencies of those assumptions. Taken together, those two documents for the first and, arguably, only time in government presentation, put our force structure in its complete strategic and military context.

He defined the concepts underpinning defence planning - the wars most likely and possible to occur, and the relevance of warning time in analysing the burdens these would place on our defenders. A disciplined relationship between national strategy, 'self-reliance'; military strategy, 'defence in depth, layered defence and denial'; geographical dimension, 'our approaches'; force-structure determinants prioritising the most likely threat for the force in being, least likely but plausible, for an expansion base; and resources, industry policy and realistic financial requirements.

The remorseless, detailed, systematic argument for a concrete structure from a distilling of the valid elements of an often politically charged analysis of our strategic circumstances has never been bettered. Dibb is loathed not so much for his plan, but for disagreement with the distillation of the day. New circumstances have changed some previously valid strategic assumptions and rejected, invalid components of the 1980s strategic arguments are devotedly held largely for ideological reasons. Shooting Dibb is shooting the messenger. It was the government of the day that adopted his views and detailed his strategic assumptions. Critics do not delve too deeply into the disciplined linkages that he forged between national strategy, military strategy, geography and force structure. To do so leaves a critic essentially saying that defence of our approaches does not matter. This is not saleable in an environment where defending those approaches has become harder rather than easier due to the exponential growth of military capabilities in our region. To dismiss his argument with a wave of the hand is politically possible. To confront it in detail risks appearing a fool. Upon appearing a fool, a threat emerges to one's political saliency. Australians, when they turn their attention to defence, perceive a threatening environment at least 
long term. When they consider a response, they start with what will guarantee our approaches. They approve our alliances but none think that we are a better partner if we are not making a devoted attempt at defending ourselves.

We have been at war or in heavy peace-enforcing/keeping operations for most of the time since Dibb reported and, for most of that, outside our areas of direct military interest (ADMI) and primary strategic interest (APSI). With few exceptions, none of that, however, has invalidated the argument that was first presented by the Fraser Government but then detailed by Dibb that we can contribute to operations broader afield than the 10 per cent (military interest)/ 25 per cent (strategic interest) of the earth's surface, with the forces recommended for that closer zone. Few can identify in their writings the prescience of the example attached to the claim in the 1987 White Paper: 'For example, our guided missile frigates equipped with Seahawk helicopters are capable of effective participation in a US carrier battle group well distant from Australia's shores.' Read the Kuwait War. The Timor commitment certainly tested the assumptions, but didn't defeat them (just).

Nevertheless, some aspects of experience have undermined the exclusive focus on the priorities to which Dibb responded. Firstly and importantly, finances. In Dibb's day, defence enjoyed about 2.3 to 2.5 per cent of Australia's GDP and around 9 per cent of the budget. Dibb was clear that the force structure he recommended required that allocation and a routine 3 per cent real growth. That was obtained through the 1980s with the massive reforms of government defence industries and restructuring of Defence. Defence obtained the 3 per cent as production was closed and privatised and the savings kept by the department. Government assumptions that industrial employment would be sustained as the private sector established export standard in production and foreign primes moved in were validated.

Underlying expenditure, however, was not sustained. Defence took a massive 'peace dividend' at the end of the Cold War and, in the last 15 years, defence expenditure has rarely hit the 2 per cent mark and is closer to 6 per cent of the budget. At 2.3 per cent we would routinely be spending AU\$5-7 billion per annum more on defence now. Consider our force structure if that was the case. The most 
obvious large reduction in response was in Dibb's recommended navy. We have got nowhere near his 17 tier-one and tier-two ships. The size of the force was based on calculations about anti-submarine warfare (ASW) requirements at the choke points to Australia's approaches. An at-the-time non-existent but projected submarine capability in the region has emerged, but the platforms don't deal with it. For a time, neither were the ASW-capable helicopters prioritised, but that is being addressed. Overall, the task for Australia's forces in our area of direct strategic interest has become more difficult, and the impact of purchases that are not based on serious prioritisation is becoming much more damaging to achieving the objectives of the core effort.

A second factor has been the emerging priority of stabilisation arrangements in our region and wars in the Middle East. The latter have had less impact, but soldiers in the field now require kit that was not anticipated in Dibb's time. That expenditure, however, has been small compared with the cost of the amphibious capabilities that are required for stabilisation arrangements in our region. This was a weakness in 1980s policy. That was not Dibb's fault. Though the contemporaneous response to the coup in Fiji demonstrated the need for an amphibious capability it was not until the 1994 White Paper that the government addressed it. The issue identified was picked up in equipment terms by subsequent governments. None of this would have been problematic in better financial circumstances.

The major contribution our service personnel have made in the various conflicts and operations (substantially so in current efforts in Iraq and Afghanistan with allies and in the South Pacific on our own) has embellished their long-standing record. As the issue of the day, however, it attracts, on the surface, greater public attention than the older Defence of Australia (DOA) requirement.

However, that is only on the surface. One of the assumptions of the 1970s and 1980s was that self-reliance was to be defined in an alliance context. This was a verity to which Dibb always paid obeisance. Part of the motive was that we were members of the Western alliance and should pay our dues. Just as important was the understanding that even if we needed to respond ourselves to our challenges, access to American intelligence, first-class equipment and exercises and training was vital to any successful defence of Australia. 
In contemporary terms, the value of this can be seen in the air defence of Australia's approaches we are developing. We have comprehensive satellite surveillance of our region, a product directly of the American relationship. We have the world's best over-the-horizon radar, a product in its early phases of scientific collaboration with the US. From Boeing we have an excellent airborne early warning capability. Our P-3 Orion maritime surveillance and ASW aircraft are being replaced by $\mathrm{P}-8$ Poseidons, also from an American source. Our frontline Hornets, Super Hornets, Growlers, and the coming F-35s are as good as anything in the region and further afield. We get the best variants. What keeps a defence minister up at night is the thought, 'what if all our calculations are wrong and a threat appears overnight. What can we do from a standing start?' This air defence answers the question.

Much of the Navy is not US sourced in terms of platforms. What makes the platforms work however has a lot of the United States in it. That is even so with our submarines. The Collins owes much to help from the US Navy. They get something in return. We have been experimented on. When I visited the US submarine construction facility in Connecticut I had a tour of the USS Missouri, a new Virginiaclass SSN. The captain asked me in the control room if I recognised anything. I said, 'Yes it is a Collins-class'. Exactly, he said. He had been an exchange officer in a Collins-class submarine. In his view it was the best conventional boat around. Whatever we do with our replacement submarine has to have the approval of the Americans if the platform is to succeed as well. Interestingly as our frontline aircraft are naval aircraft, when added to our ASW helicopters and other American kit, we are the largest foreign-military-sales partner that the US Navy has.

Apparently outside the Dibb realm, our biggest contemporary purchase is the landing helicopter dock (LHD) amphibious assault ship. They are potentially capable ships. If they are ever to be developed, however, in our increasingly submarine-infested environment, they cannot be put to sea unless our ASW defences improve. No likely escort capability can provide sufficient ASW support. Our old carriers were ASW carriers. These LHDs will need organic ASW capabilities as well. To do the job properly they will need onboard sonars and four to six of the new Romeo helicopters as well. They can carry 24 aircraft so their inclusion will not interfere with the Army's lift. Dibb might not have prioritised them, but in extremes perhaps we might 
get closer to the 1980s choke point objective. But perhaps not. On our own we might not go looking for trouble with platforms so valuable. In conjunction with the Americans, maybe.

I was a lucky defence minister; I was one of the few who had a 'defence afterlife' in politics. I had the job in an era when the government was forced to take defence very seriously. The self-reliance within alliances formula was perfect for the Australian Labor Party (ALP) where significant elements were highly sceptical, after the Vietnam War, of alliance commitments. In the day national security was a forefront issue in party conclaves enhanced by the relationship between defence industry and reform of Australian industry overall.

Dibb was critical to the settling of dissention within the ALP on the value of the American alliance commitment. His colleague Des Ball, whose writing shone a light on the US-Australian joint facilities, enhanced to some extent the strength of the arguments of alliance sceptics. He also, however, demonstrated the value of the facilities and the alliance to the avoidance of nuclear war and the effectiveness of confidence-building and arms control. Dibb made clear that selfreliance with its foreign policy-liberating, security-guaranteeing, industry-enhancing value, would not be affordable without the American alliance. The pair laid down a clear path that settled the minds of sceptics with the empirically based intellectual power of their argument.

Those circumstances have altered the picture post-Cold War, the power of these positions has transitioned to a new distribution of global power in a more complex international system. In terms of bipartisanship in alliance policy in Australia this has been crucial. Dibb was part of this luck. I was deeply shocked when my departmental Secretary told me that were the department to produce a white paper it would irrevocably destroy the always tense relationship between civilian and military sides. I would need to find a consultant. $\mathrm{He}$ and the Chief of the Defence Force had agreed to give him all the support necessary for the study and the ultimate white paper. There were several who might have done the job. Dibb was the only one who could have been security cleared quickly enough to do it. His reputation was embellished by the job he did for the country. It also made him a target. Unfairly, the strategic calculations were the 
government's not his. As strategic calculations have changed over time and political debate has from time to time been brutal, he has become a lightning rod.

Nevertheless as his legacy has been examined he has come up pretty well. A new term is likely to come into use in alliance relationships. It is not 'expeditionary'. That is still there. It is 'integration'. As the US shifts the weight of its capability to the Asia-Pacific region it will look to allies to make up for shortfalls in its capabilities. The US Marine Corps, for example, will look with fascination on our LHDs.

Still, all things considered, any Australian government will want to be able to answer the question ordinary Australians always ask. Can we defend our approaches? If an enemy gets ashore can our Army deal with it before it seizes a bargaining chip? We know the answers on layered defence. We have thought about it in detail. We understand the essence of our strategic geography. We are nearly 30 years on from the time of Dibb's most significant contribution to our national defence. His legacy remains real. It endures. 
This text is taken from Geography, Power, Strategy and Defence Policy: Essays in Honour of Paul Dibb, edited by Desmond Ball and Sheryn Lee, published 2016 by ANU Press, The Australian National University,

Canberra, Australia. 